\section{THE LAND WORK OF THE BELGIAN ANTARCTIC EXPEDITION.}

A $\mathrm{T}$ the present moment the Antarctic problem is mainly A that of the forthcoming expeditions, and during their preparation every fact bearing upon the conditions, physical and official, in which the scientific staffs will have to work has a special interest. So far the Belgian expedition has yielded most information of a useful kind, and the two latest papers of its enthusiastic geologist, M. Henryk Arçtowski, are of more than usual value. ${ }^{1}$ The general account of the expedition contains nothing that will be new to our readers. M. Arçtowski concludes it by the observation that while the scientific results have been varied and satisfactory, the chief outcome is that the great public has been acquainted with the paucity of our knowledge of the Antarctic area, and shown how trifing is the work accomplished com. pared with that which remains to be done.

The paper in the Geographical Journal is the most detailed and valuable description of land on the confines of the Antarctic region that has ever been published. It records, in the form of a narrative from day to day, the exploration of Belgica Strait, the new channel discovered by the expedition, separating the Palmer Archipelago from the mass of Graham Land with which those islands were form erly supposed to be continuous.

The twenty landings which the importunity of M. Arçtowski induced the reluctant commander to permit are described in detail; but, as none of the new names given by the expedition are employed, and practically no other names exist in that region, it is impossible to follow the description without reference to the sketch map on which the landings are marked. This is accordingly reproduced as Fig. I.

The opportunities of landing were numerous, but the time allowed on shore was usually absurdly inadequate to the im. portance of the work of surveying and geological investigation. In the only case where a week was spent on shore practically nothing was done because of the unnecessarily heavy equipment insisted on by the conmmander-a sailor of no scientific qualifications, and apparently devoid of synupathy with the more important objects of the expedition. Still, it must be remembered that but for de Gerlache's burning ambition to reach a high southern latitude (an ambition which was not gratified) the expedition would never have been dispatched, and no scientific work of any kind would have been done. The following paragraphs are a much-abridged summary of M. Arçtowski's narrative.

At 7 p.m. on January 23, 1898, having passed the South Shetlands, the Belgica was close to a headland, which probably was Cape Cockburn, but as she went on

1"L'Exódition Antarctique belge," Rez'ue Géuérale des sciences, 12 (rgo1), 87-94. "Exploration of Antarctic liands," Geographical Journal, 17 (x901), $150-180$.

No. 1639 , voL. 63$]$ the charts became valueless. What was seen corresponded to nothing that they represented, and Lecointe proceeded to construct a fresh chart from his own surveys. At $10.30 \mathrm{p} . \mathrm{m}$. the first landing was made on an island in Hughes Bay (see I. on map, Fig. I). A considerable part of the island was uncovered. The upper part was like a lava-flow of prismatic structure. Lower down the rock was completely cracked, and seened to decompose in large superimposed blocks with straight surfaces. It was an eruptive rock of great density, very hard and brittle, and ringing on a blow with the hammer. It was not basaltic, but of granitic structure and very fine-grained; its colour was a very deep green, and $M$. Arçtowski thought that he saw small crystals of hornblende ; if so, the rock would be a diorite.

On January 24 the second landing was made (II. on

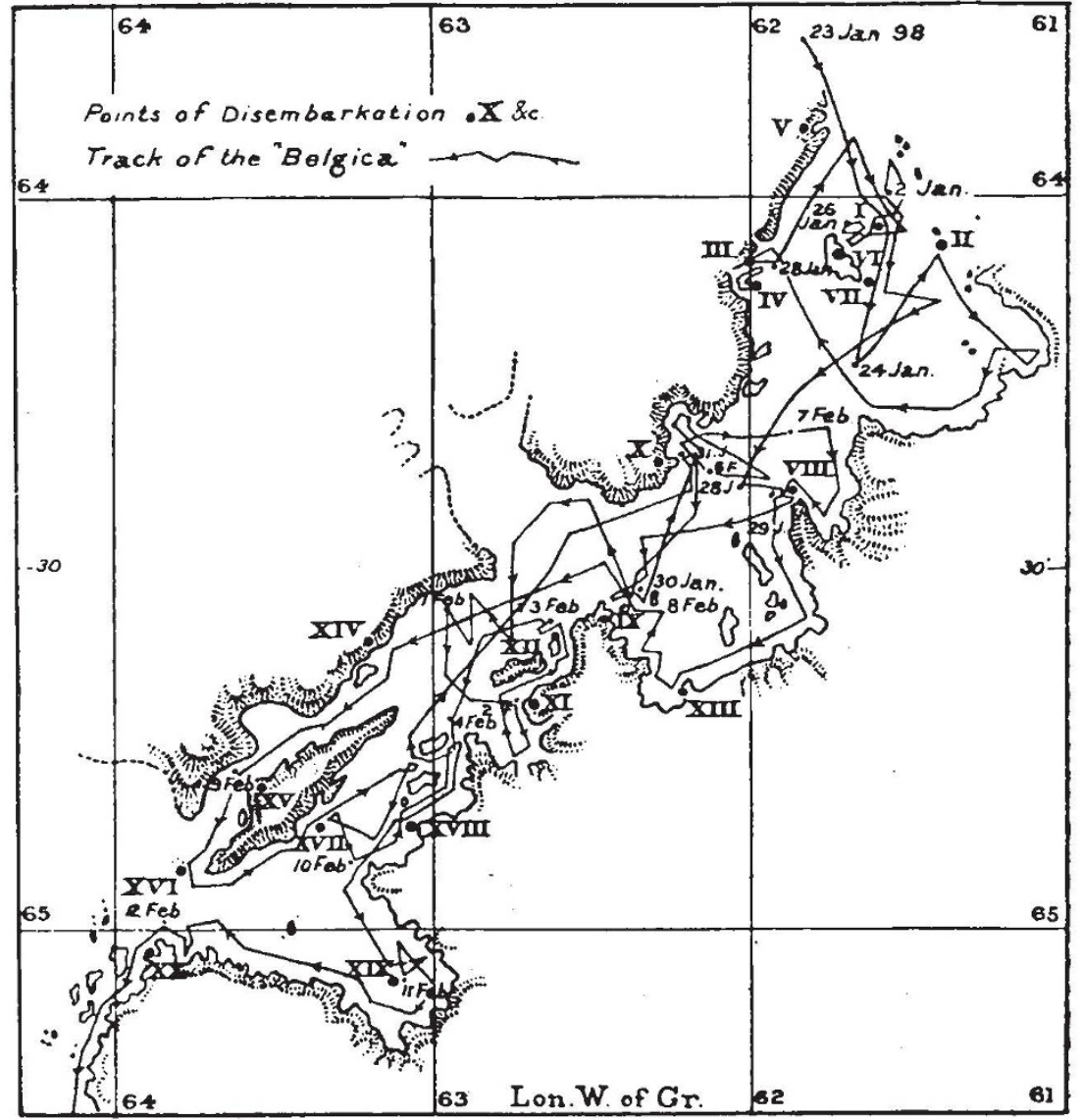

FiG. 1.- The track of the Belgian Antarctic Expedition in Belgica Strait. From the firographical fournal. map, Fig. 1) on a small narrow island, no more than 100 feet high and almost free from snow; it appeared to be surrounded by a close colonnade, on account of the regular vertical cracks in the rock, which were doubtless produced by extreme cold. The surface was frequently mammilated and worn smooth by the ice. Here, M. Arçtowski says, "A little sandy clay mixed with guano was found in small pockets between the rocks, and while examining this I had the pleasure of discovering the first Antarctic insect, almost microscopic in its dimensions." The general result of that day's nautical work had been the discovery of an elevated land where Friederichsen's map bore the inscription, "No land in sight (Larsen)." Towards the east and south an uninterrupted coast-line stretched as far as the eye could 
reach, but in the south-west a large strait opened into Hughes Bay, and this it was necessary to explore. The quantity of snow on the land was found to be formidable. The westerly and northerly winds coming from the ocean doubtless brought great falls of snow, and this was always accumulating, mountains of ice were reared on the top of the mountains of rock. So far as could be judged from the ship, the ice was nowhere uncovered, but thick snow seemed to lie on the glaciers down to the very edge of the sea.

About midnight a landing was made in a little bay (III. on map, Fig. I), where a ground moraine, or something closely resembling one, was found. There was water behind it and then a cliff of ice, the end of a great glacier which covered the whole slope of the mountain. Although it was growing very dark and the specimens were collected hurriedly, more than ten different varieties of rocks were obtained, none, however, of sedimentary formation.

The next landing was for three hours, on the 25 th, in lat. $64^{\prime \prime} 6^{\prime} 24^{\prime \prime}$ S., long. $61^{\prime \prime} 59^{\prime} 30^{\prime \prime} \mathrm{W}$., on the promontory of an island (IV. on map, Fig. I), and it was not without difficulty that all the delicate instruments were got ashore on the steep rocks. "Cook and I," says M. Arçtowski, "made use of Canadian snow-shoes to visit the higher part of the island, and found them a great aid in crossing the snowy slopes, which were usually gentle, though there were dangerous crevasses in places. A thick mantle of snow stretched to the crest of the promontory and stopped abruptly, the further side being perpendicular. . . . It was a region quite alpine in its character, but completely buried, in glaciers. The snow-fields rose towards the interior forming a veritable ice-cap, terminating in a perfectly continuous sky-line. . . . Lower down the relief of the land could be divined beneath its robe of snow, and here and there a bare peak pierced the covering. Nothing like an exposed chain of mountains was to be detected, although near the sea a coast range could be made out, its sides cut by valleys through which glaciers of various sizes made their way. Along the shore some of the promontories were bare, but on the lower ground the ends of the glaciers were covered by a field of snow, and were for the most part confluent, forming a plateau of ice which gave origin to icebergs. That valleys exist, though they do not show on the surface, is clear from the differences in the size and appearance of the glaciers. The largest are of gentle slope, the smaller steep and broken by numerous crevasses. Some of the glaciers suspended from the cliffs were of extraordinary dimensions. Thus by the appearance of the surface of the ice, without any other evidence, one could see that the configuration of the buried land was complicated, and underneath each glacier there must be a great excavated valley, along the bed of which the ice glides downward. The existence of valleys is very interesting, for it points to a time when there was no ice, but dry land being eroded by the running water of rivers. On the other hand, the thought of these buried valleys brought to my mind the channels of Tierra del Fuego as they must have appeared in the glacial period, when the end of the Andean chain lay under just such an ice-sheet."

In the afternoon of Wednesday, January 26, Cook, Amundsen and Arçtowski landed on Two Hummocks Island (VI. on map, Fig. 1), which was narrow and entirely covered with a thick mantle of snow, giving it a convex appearance. Two pyramidal mountains projected like nunataks, contrasting with the general smooth outline. The party landed on the north coast in the hope of being able to climb one of the mountains, and found that the shore was formed by a cliff of ice, with only a few promontories of bare rock. The ice was not found to be actually immersed in the water at any point; a very narrow strip of bare rock always separated it from the sea. A little snow rested even on the roches moutonnées, which bordered the shore, either awash or rarely rising so much as a yard or two above the surface, and the sea-leopards were sleeping upon them very tranquilly. The rock of the island was a grey granite, with thick and very regular veins of a dark and compact green rock, and also smaller red veins. There were some erratics, which might have been carried by floating ice.

At 2 p.m. on the 28 th an island was visited which showed an appearance of stratification (VIII. on map, Fig. 1), but the whole surface was found to be a smoothly glaciated rock of eruptive origin, traversed by grey compact veins twenty feet thick.

On Saturday, January 29 , the weather was calm; the fog had cleared away and revealed a niarvellous scene. On every side the thick white covering descended to the sea, and only the most abrupt slopes were free from snow; perpendicular cliffs and steep hillsides were characteristic of all these coasts. A cliff which bordered a submerged valley where an immense glacier debouched showed an appearance of vertical stratification, but the ninth landing sufficed to prove that this appearance was due merely to cracks in the rock, as in all previous cases. This may possibly be an effect of extreme cold, for the rockes moutonnies, which are preserved from rapid changes of temperature by a covering of snow during most of the year, do not exhibit such cracks, or only to a slight extent.

The only attempt at a land journey must be described in the author's own words. It commenced on Sunday, January 30. "The commandant decided to accompany the land-party, ... but the preparations which had to be made were too elaborate, and the projected excursion was doomed to failure before it set out. In order to succeed, it would have been necessary to carry all the absolute necessaries on our backs and make a great and sustained effort, being prepared, if the route was bad, to return and choose a better way. ... We took with us two sledges of Nansen's pattern, sleeping bags, a silk shelter tent, a little aluminium stove, such as was used by Jackson, Norwegian $s k i$, Canadian snow. shoes, ice-axes, a 40-foot rope of raw silk, provisions for a fortnight, even changes of underclothing, and all the in struments after that. Certainly far too much baggage. ... We landed on a little promontory at the head of a fine bay, where a large glacier entered the sea and the snow lay down to the water's edge (X. on map, Fig. $2^{1}$ ). There was no difficulty in getting ashore, but the sledges were horribly heavy... At a height between 400 and 600 feet we had to cross several crevasses, which were narrow and spanned by snow-bridges solid enough to allow our loads to pass without difficulty. Higher up a great snow. field stretched before us, whence we could look down upon the glacier which cascaded towards the bay. ... At 2.30 p.m. during lunch I placed the black-bulb thermometers on the snow, and, although the sun was slightly veiled they showed readings of 102.6 and $86^{\circ}$ Fahr., while the temperature of the air, measured by a sling thermo. meter, was only $34^{\circ} \cdot 2$. The strength of the solar radia. tion made us all feel very warm. We enjoyed an ex. tensive view towards the south, and saw the high mountains on the opposite side of the strait diminishing gradually in height towards the east; the direction of the chain seemed to be north-east and south-west. . . . At 7 p.m. we were still mounting upwards, the weather being remarkably good, and the view of Graham Land grew finer and finer. The relief of that land, although excessively varied, is singularly softened by the glaciers and the accumulated snow, so that it can only be because the valleys, hollowed by the running water of some former epoch, are so deep that a few crests and very abrupt slopes remain bare. At the height of 1600 feet 1 Fig. 1. in this article.

No. 1639 , vol. 63] 
we were stopped by a crevasse more than thirty feet wide, which we could not cross, and other crevasses appeared beyond it, the whole glacier having a terraced structure. ... All Tuesday we were dragging our loads uselessly towards a hill in the west, but in that direction also we were stopped by numerous crevasses. . . . Again we had to retrace our steps to the ice-plain to pass the night, and there we left our camp for the two following days, seeing that it was impossible to reach any high summit. ... From the summit of the more distant nunatak, Cook and $I$ had a good view of the mer de glace in which the large glacier terminated at the head of the bay where we landed. Although the broken fragments could not give rise to icebergs as they entered the water, it seemed quite possible that in winter, when the bay is frozen, enough ice might accunsulate to form one or more bergs. In any case, it appeared certain to me that the bottom of this great valley extended below the level of the sea; and I was also led to believe, judging from the distances which separated the nunataks and the angle of slope of the walls, that the same held good for the valley in which we camped. We found some lichens and mosses on the nunataks."

On Sunday, February 6 , the party got on board the Belgica, and steered towards the east, in order to continue the survey of the coast of Graham Land. The airtemperature was high all that day, with a maximum of $45^{-} \mathrm{F}$. At night it rained, at times very heavily, and it must have produced a great effect upon the snow-fields, a much greater effect, probably, than a day of strongr sunshine.

The party succeeded in landing on February 7 at the base of a granitic cliff, near which, upon a little promontory, a metamorphic schist was discovered in contact with the granite (XIII. on map, Fig. 1). The direction of the strata was north-west and south-east, and their dip towards the north was about $45^{\circ}$; a very friable schist alternated with a dark quartite, and dark green strata of a highly metamorphosed rock.

The fourteenth landirig (XIV. on map, Fig. I) was on a large island. $M$. Arçtowski thus describes it: "I saw a channel which separates it in the south-west from another land; and to the north-west the seahorizon was unbroken-it was the Pacific Ocean. I saw this confirmation of my theories ${ }^{1}$ with much pleasure; there was no doubt that we were on the west coast of the continental land symmetrically placed with regard to the Southern Andes. There is no passage to the east, and the Biscoe Islands form a parallel chain belonging to the mountain system of Graham Land. . . . We remained some time on the strip of bare rock which was exposed between the field of névé and the sea. It was the same black granitoid rock traversed by thick veins and narrow threads of quartz; and there was a great varicty of erratic blocks, including specimens of basalt, breccia, several blocks of conglomerate, and some fragments of quartzite. A cave was found in the large-grained porous ice-wall, along the uncovered bed of which a little stream flowed, the first glacier stream I had seen. It came from the direction of a nunatak, and consequently could not have pursued its course from a long distance under the ice ; in its bed there were rolled pebbles of eruptive rocks."

On Vednesday, February 9, at 7.30 a.m., the fifteenth landing was made ( $\mathrm{XV}$. on map, Fig. I). The whole coast appeared like one great roche moutonnie entirely free from snow, everywhere smoothly polished and scored with sharp grooves, often very deep, running in all directions and crossing each other. The larger were vacant, but others were filled with thin leaves of rock. and some with compact grey veins giving the rock a schistose appearance. The surface of the granite was strewn with splinters split off by the effects of radiation, 1 Finll. Soc. Ficol. France, 1:95, p. 59:

No. 1639 , voL. 63$]$ usually from one-third to two-thirds of an inch thick, and about a foot in diameter. There were no erratic blocks. The rocks were bare up to a height of about I jo feet, but from this level snow uniformly covered the island and gave rise to a trickle of water, forming cascades, under which an abundant vegetation of mosses and algie had accumulated. A few tufts of moss were found here and there among the stones. The sun shone strongly, and the bare rock grew quite warm. At $8 \mathrm{a} . \mathrm{m}$. on the Belgica, when the air temperature was $4 \mathrm{I}^{2} \mathrm{~F}$., the black-bulb thermometer in the sun read $87^{\circ} .8$, hence the splintering of the surface of the rocks could easily be understood. At 10.30 the Belgica passed the cape at the south end of the mountainous island, and the recording thermometer fell, while the hygrometer rose sharply as the influence of the ocean made itself felt : and in the distance great icebergs could be seen in the open Pacific. At II o'clock the sixteenth landing was made on one of a group of twelve small low islands (XVI. on map, Fig. 1). Lecointe landed for the noon observation of the sun, making use, as before, of an artificial horizon; Arçtowski, Racovitza, Cook and Janco accompanied him. The whole islet was covered with moist snow almost to the water's edge ; a remark. able difference in the height of the snow-line being observable in the short distance separating the fifteenth and sixteenth landings. All the islets of the neighbourhood had the same appearance, like great whale-backs rising from the sea. The polished rock extended to just below the surface of the water, and there were also several ylaciated rocks scarcely emergent. The whole group seems to form a plateau which has been profoundly glaciated, and of which only the higher portions now appear; but this plateau has nothing, in .11. Arçtowski's opinion, in common with the continental shelf, the whole of the district presenting clear evidence of being a submerged region. From another point of view, these islands are by no means to be considered as the stumps of mountains worn down by marine erosion ; they afford evidence of a great extension of glaciers in some bygone period. The whole of Belgica Strait had probably at one time been filled by a great glacier which flowed to the Pacific. The cutting off of the summits of these islands may be its work.

At noon on February to the eighteenth landing was made, almost opposite the seventeenth, on the other side of the large channel (XVIII. on map, Fig. I). It was at the base of a pyramidal mountain of red rock, very different in appearance from the surrounding scenery. A great band of red granite seemed to traverse the region from north-north-west to south-south-east. The interesting feature of this landing was the discovery of a moraine, at least 70 feet in height, which was set against the inountain-side along part of the beach in the direction of the channel. The rock itself was highly glaciated to just below the level of the water. Here we must once again give the author's own words: "The commandant showed himself very obliging, but with a little goodwill we could have landed in many other places and collected much more geological material than we did. For this eighteenth landing he conducted me himself, but for ten minutes only. A few strokes of the oars brought us to the beach, amid cries of "Hurry up, Arçtowski!' I gave a hammer to Tellefsen, with orders to chip here and there down by the shore, while I hurriedly climbed the moraine, picking up specimens as I ran, took the direction with my compass, glanced to the left and right, and hurried down again full speed to get a look at the rock in situ; meanwhile Cook had taken a photograph of the place from the ship -..and that is the way geological surveys had to be carried out in the Antarctic."

At ten a.m. on February I I the twentieth and last landing was made on the Pacific slope of the Needles, 
which form the northern cape of Graham Land (XX. on map, Fig. I. and view Fig. 2). In places the beach was quite free from snow, elsewhere there were small glaciers clinging to the slopes of the mountain and terminating seawards in cliffs of ice. The steep rocky slopes above were absolutely bare up to a height of 700 or 1000 feet, and beyond that rose fields of névé. Two of the party climbed a little ridge running at right-angles to the range of the Needles. An inclined plane of snow, interrupted here and there in the upper part by transverse crevasses easy to cross, led them to the rocky wall, which there was no difficulty in climbing, thanks to the numerous joints widened by weathering so as to cut up the face of the rock into superimposed blocks, and thanks also to the narrow chimneys down which the clébris of the rock slipped. It is remarkable that these rocks remained quite bare at an elevation far above the snow-line. It is not sufficiently accounted for by the steepness of the slope, though that would make it possible for only a small quantity of snow to accumulate; but the dark walls were so strongly heated by the sun that the snow was actually melted. In making the ascent it was found that the low cloud, characteristic of these regions, was very thin and level on both the lower and upper surfaces, the belt of mist having been passed through between the altitudes of 150 and 300 feet, and above that there was an absolutely clear sky and dazzling sunshine, while the cloud extended as a smooth grey sea underneath. If such a condition often occurs, it is easy to see how the higher rocks become free of snow in summer, while those near sea-level remain covered.

After this landing the Belgica entered the Pacific, turned southwards into the ice-pack, and for a year drifted hither and thither, fast in the ice out of sight of land.

THE INTERNATIONAL ASSOCIATION OF ACADEMIES.

$A \mathrm{~N}$ account by M. Gaston DarA boux, permanent secretary of the inception and first meeting at Wiesbaden of this International Association, was given in NATURE for July 12, 1900. To the January number of the Journal des Savants M: Darboux contributes a further article on the same subject, in which, after again sketching the events which led to the rise of the Association, he gives an account of the Paris meeting and the arrangements for future work.

In this interesting article it is explained that the Royal Society and the Paris Academy took the initiative in the formation of this important Association, the advantages of which were pointed out by Lord Lister, as president of the Royal Society, in a letter dated November I7, I898, addressed to the president of the Academy of Sciences of Paris. Among the questions of the first importance is that of the Catalogue of Scientific Papers, already commenced single-handed by the Royal Society. To carry this out completely it has been estimated that in the domain of the positive sciences alone the annual catalogue should comprise seventeen volumes and about two hundred thousand entries, a task evidently capable of being successfully accomplished only by combined international effort.

The academies and societies represented at the No. I 639, voL. 63$]$
Wiesbaden conference decided to found an International Union of the principal scientific bodies of the whole world under the name of the "International Association of Academies"; the members of this Association being as follows:-

(I) The Royal Prussian Academy of Sciences, at Berlin.

(2) The Royal Society of Sciences, at Göttingen.

(3) The Royal Saxon Society of Sciences, at Leipzig.

(4) The Royal Society, at London.

(5) The Royal Bavarian Academy of Sciences, at Munich.

(6) The Academy of Sciences, at Paris.

(7) The Insperial Academy of Sciences, at St. Petersburg.

(8) The Royal Academy, at Rome.

(9) The Imperial Academy of Sciences, at Vienna.

(I0) The National Academy of Sciences, at Washington.

The following academies were also invited to take part :-

(I) The Royal Academy of Sciences, at Amsterdam.

(2) The Royal Belgian Academy of Sciences, Literature and the Fine Arts, at Brussels. 